\title{
Human Peripheral Blood-derived Mast Cells Contribute to Epithelial to Mesenchymal Transition in Bronchial Epithelial Cells in the Presence of IL-1 $\beta$
}

\section{Xian-Song Wang ( $\sim$ xiansongw@hust.edu.cn )}

Department of Pathology https://orcid.org/0000-0002-2870-5542

\section{Li Xie}

Tongji Hospital of Tongji Medical College of Huazhong University of Science and Technology

Kaiyu Zheng

Huazhong University of Science and Technology Tongji Medical College

\section{Research}

Keywords: asthma, mast cell, bronchial epithelial cells, epithelial to mesenchymal transition, airway remolding, interleukin- $1 \beta$, transforming growth factor- $\beta 1$

Posted Date: June 30th, 2020

DOl: https://doi.org/10.21203/rs.3.rs-37988/v1

License: (c) (i) This work is licensed under a Creative Commons Attribution 4.0 International License. Read Full License 


\section{Abstract}

Background: Bronchial epithelial to mesenchymal transition $\triangle E M T$ is an important mechanism for the airway remodeling in asthmatics. Mast cell is one of the critical effector cells in pathogenesis of asthma. Although mast cells have been shown to release a plethora of pro-fibrotic factors with the potential to induce EMT, it is not clear whether mast cells also directly have an impact on the bronchial EMT. In this study, we investigated the contribution of human mast cells to EMT in human bronchial epithelial cell line 16-HBE.

Methods: Human peripheral blood-derived mast cells were co-cultured with 16-HBE cells. The protein and mRNA expression of E-cadherin and vimentin in 16-HBE cells were analyzed by Western blot and quantitative real-time PCR. A scratch wound assay was performed to evaluate the migratory properties of the 16-HBE cells.

Results: Mast cells alone failed to produce significant effects on the epithelial morphology, mobility, and expression of E-cadherin and vimentin. However, mast cells in combination of interleukin (IL)-1 $\beta$ significantly decreased E-cadherin expression but increased vimentin expression in the co-cultured 16HBE cells, which exhibited a spindle-like appearance with reduced cell junctions and enhanced migration. The down-regulation of E-cadherin expression and up-regulation of vimentin expression were not abrogated by the transforming growth factor (TGF)- $\beta 1$ neutralizing antibody.

Conclusion: Mast cells combined with IL-1 $\beta$, not mast cells alone, were able to induce EMT in 16-HBE cells through a TGF- $\beta 1$-independent mechanism. The results of in vitro culture suggest the possibility that mast cells contribute to human bronchial epithelial EMT in the asthmatic airway tissues with high level of IL-1 $\beta$.

\section{Background}

Chronic inflammation and structural remodeling are two prominent pathological features in the airways of bronchial asthma. Airway remodeling is highly correlated with asthma severity and decreased lung function in asthmatics [1, 2]. Epithelial to mesenchymal transition (EMT) is a complex biological process in which epithelial cells lose their epithelial features and become mesenchymal fibroblast-like cells [3]. The bronchial epithelial cells can be trans-differentiated into myofibroblasts with highly synthetic activity through EMT [4]. Increased myofibroblasts in the submucosa excrete excessive extracellular matrix proteins which result in airway wall thickening, a characteristic change of airway remodeling $[5,6]$. Thus, EMT is currently considered to be an important mechanism for the airway remodeling in asthma.

A plethora of pro-fibrotic factors, mainly growth factors and cytokines such as transforming growth factor (TGF)- $\beta 1$, epidermal growth factor (EGF), fibroblast growth factor (FGF)-2, connective tissue growth factor (CTGF), interleukin (IL)-6, IL-1 $\beta$ and tumour necrosis factor (TNF)-a, has been shown to be involved in the EMT process $[7,8]$. These factors can be produced from the damaged bronchial epithelial cells and other structural cells, as well as the inflammatory cells in the airway tissues of asthmatics $[9,10]$. Of 
these factors, TGF- $\beta 1$ is the most potent EMT inducer identified so far, which directly initiates EMT in human bronchial epithelial cells $[11,12]$. Some cytokines such as TNF-a, IL-1 $\beta$ and IL-6 synergize with TGF- $\beta 1$ to induce ETM of human bronchial epithelial cells $[13,14]$.

Eosinophils, mast cells and T lymphocytes are the prime inflammatory cells infiltrated in asthmatic airways. Mast cells are believed to be key effector cells that are responsible for elicitation and maintenanceof airway inflammation through the releasing ofan array of inflammatory mediators $[15,16]$. Mast cells are also the important source of the pro-fibrotic cytokines and growth factors as mentioned above $[16,17]$. Although these pro-fibrotic factors, especially the growth factor TGF- $\beta 1$, have been proved to be EMT inducers, it is not clear whether mast cells also directly have an impact on the bronchial EMT. IL-1 $\beta$ is one of the most important inflammatory factors implicated in the inflammatory response in the airways of asthmatics $[10,18-20]$. In addition to powerful proinflammatory and pro-fibrotic effects, IL-1 $\beta$ is also capable of activating human mast cells to produce multiple cytokines, such as IL-6, 8, 13 and monocyte chemoattractant protein-1 (MCP-1) [21, 22]. In this study, we investigated the effect of mast cells on EMT by examining the alteration of morphology, expression of EMT marker proteins and mobility in human bronchial epithelial cells co-cultured with human peripheral blood-derived mast cells in the presence and absence of IL-1 $\beta$.

\section{Methods}

\section{Reagents}

Recombinant human stem cell factor (SCF), IL-1 $\beta$, IL-3, and IL- 6 were purchased from Peprotech (Rocky Hill, NJ). Serum-free methylcellulose medium (SF H4236) was purchased from StemCell Technologies (Vancouver, Canada). Dulbecco's phosphate-buffered saline (PBS), Iscove's modified Dulbecco's medium (IMDM), RPMI-1640, fetal calf serum (FCS) and bovine serum albuminwere purchased from Gibco BRL (NY, USA). Rabbit anti-human E-cadherin,mouse anti-human vimentin monoclonal antibody (mAb) from Boster (Wuhan, China). Mouse anti-TGF- $\beta 1$ mAb was from R\&D Systems (Minneapolis, MN). Horseradish peroxidase-conjugated goat anti-rabbit IgG and horseradish peroxidase-conjugated goat anti-mouse IgG were purchased from Beyotime Biotechnology (Shanghai, China).

\section{Mast Cell Cultures}

Human mast cells were cultured according to the methods reported by Wang et al [23]. Briefly, mononuclear cells were separated from peripheral blood of healthy volunteers by density-gradient centrifugation. Lineage-negative cells were then purified from the mononuclear cells by depletion of cells expressing a panel of lineage antigens, CD2, CD3, CD11b, CD14, CD15, CD16, CD19, CD56, CD123, and CD235a using human Lineage Cell Depletion kit (Miltenyi Biotech, Bergisch Gladbach, Germany) according to the manufacturer's instructions. The isolated lineage-negative cells were cultured in serumfree methylcellulose medium containing $200 \mathrm{ng} / \mathrm{mL} \mathrm{SCF}, 50 \mathrm{ng} / \mathrm{mL} \mathrm{IL}-6$ and $5 \mathrm{ng} / \mathrm{mL}$ IL-3. After 1 week of culture, fresh methylcellulose medium containing $100 \mathrm{ng} / \mathrm{mL} \mathrm{SCF}$ and $50 \mathrm{ng} / \mathrm{mL} \mathrm{IL}-6$ was layered over the methylcellulose cultures every 7 days. After $4 \sim 6$ weeks, cells were collected and maintained in 
complete IMDM supplemented with $100 \mathrm{ng} / \mathrm{mL} \mathrm{SCF}, 50 \mathrm{ng} / \mathrm{mL} \mathrm{IL}-6$ and $10 \% \mathrm{FCS}$, and the culture medium was replaced weekly. The purity of the cultured mast cells (>98\%) was determined by calculating the percentage of positive cells stained with anti-human mast cell tryptase mAb (Chemicon International, UK) [23].

\section{Cell line}

Human bronchial epithelial cell line 16-HBE-14o (16-HBE) was used in the present study. 16-HBE cells were maintained in IMDM medium supplemented with $10 \%$ heat-inactivated FCS, $100 \mu \mathrm{g} / \mathrm{ml}$ penicillin and streptomycin, at $37^{\circ} \mathrm{C}$ and $5 \% \mathrm{CO}_{2}$ in humidified atmosphere. 16-HBE cells were used for the next experiments when they reached $80 \%$ confluence.

\section{Cell co-culture experiments}

16-HBE cells were cultured in 6-well plates at $5 \times 10^{4}$ cells per well with IMDM medium containing $100 \mathrm{ng} / \mathrm{mL} \mathrm{SCF}, 50 \mathrm{ng} / \mathrm{mL} \mathrm{IL}-6$ and $10 \%$ FCS. For the co-culture experiments, mast cells $\left(2.5 \times 10^{5} /\right.$ well $)$ with or without $10 \mathrm{ng} / \mathrm{mL}$ of IL-1 $\beta$ were added to $16-\mathrm{HBE}$ cell cultures and incubated for 3 days. In some experiments, co-culture of $16-\mathrm{HBE}$ cells and mast cells were performed in the presence of mouse antiTGF- $\beta 1 \mathrm{mAb}(2 \mu \mathrm{g} / \mathrm{ml})$. The total number of cells in each well is the same. After 3 days of co-culture, the suspended mast cells, adherent $16-\mathrm{HBE}$ cells, and cell medium in plates were collected for the subsequent experiments.

\section{Western blot}

16-HBE cells in 6-well plates were collected by digesting with trypsin and lysed in $50 \mu \mathrm{L}$ lysis buffer ( $1 \mathrm{~mL}$ RIPA buffer containing $10 \mu \mathrm{L}$ PMSF). Lysates were centrifuged at $1200 \mathrm{rpm}$ for $15 \mathrm{~min}$ at $4{ }^{\circ} \mathrm{C}$. Total protein concentrations in supernatants were quantified by the BCA Protein Assay Kit (Beyotime Biotechnology, Shanghai, China) according to the manufacturer's instructions. Denatured total protein of $50 \mu \mathrm{g}$ per well was separated by SDS-PAGE (10\% separation gel, $5 \%$ stacking gel), followed by transfer onto polyvinylidene fluoride membranes (Millipore Corporation). The membranes were incubated with Tris-base sodium solution containing Tween-20 and $5 \%$ fat-free milk for $1 \mathrm{~h}$ at room temperature to block non-specific binding sites, then incubated with primary mAb against E-cadherin (1:100) or vimentin (1:100) overnight at $4{ }^{\circ} \mathrm{C}$. Next, the membranes were washed and incubated with horseradish-peroxidase conjugated goat anti-rabbit/mouse secondary antibody (1:3000 dilution, Beyotime Biotechnology, Shanghai, China) for $1 \mathrm{~h}$ at room temperature. The immunoblots were detected with enhanced chemiluminescence (Servicebio, Wuhan, China) and exposed to GeneGnome HR Model (Synoptics Ltd, Cambridge, UK). The protein levels were quantified as ratios to the GAPDH band intensities by using GeneTools software.

\section{Quantitative RT-PCR}

Total RNA was extracted from the 3 days of co-cultured 16-HBE cells and mast cells respectively with Trizol Reagent. RNA was reverse transcribed to CDNA using oligo-dT primers, and quantitative RT-PCR was then performed using StepOnePlus system (ABI, Foster, CA) and SYBR Premix Ex Taq kit (TaKaRa 
Biotechnology, Dalian, China) following the manufacturer's protocol. The PCR amplification consisted of one cycle at $95^{\circ} \mathrm{C}$ for $2 \mathrm{~min}$, followed by 40 cycles of denaturation at $95^{\circ} \mathrm{C}$ for $10 \mathrm{~s}$, annealing at $60^{\circ} \mathrm{C}$ for $10 \mathrm{~s}$, and then extension at $72{ }^{\circ} \mathrm{C}$ for $15 \mathrm{~s}$. The expression of housekeeping gene GAPDH was used for normalization. Relative gene expression was calculated using comparative cycle threshold $\left(2^{-\triangle \Delta \mathrm{Ct}}\right)$ method. No PCR product was amplified in the negative control. The sequences of the primers are as follows: E-cadherin, forward 5'-GAGAACGCATTGCCACATACAC-3' and reverse 5'-

GAGCACCTTCCATGACAGACCC-3'; vimentin, forward 5'-ATCTGGA TTCACTCCCTCTGGTT-3' and reverse 5'-CGTGATGCTGAGAAGTTTCGTT G-3'; TGF- $\beta 1$, forward5'-ACCGCAACAACGCCATCT-3'and reverse 5'CCAAG GTAACGCCAGGAAT-3'; GAPDH, forward 5'-GGAAGCTTGTCATCAATGGA AATC-3' and reverse 5'TGATGACCCTTTTGGCTCCC-3'.

\section{Measurement of TGF- $\beta 1$ in supernatants}

TGF- $\beta 1$ contents in the culture supernatants were measured using a commercial enzyme linked immunosorbent assay kit (Boster, Wuhan, China) according to the manufacturer's instructions.

\section{Scratch wound healing assay}

Wound healing assay was performed as described by Doernerand Zuraw [13]. Briefly,16-HBE cells were seeded in 6-well plates at a density of $5 \times 10^{4} /$ well and cultured in IMDM containing $100 \mathrm{ng} / \mathrm{mL} \mathrm{SCF}$, $50 \mathrm{ng} / \mathrm{mL} \mathrm{IL}-6$ and $10 \%$ fetal calf serum. After 24 hours, mast cells $\left(5 \times 10^{5} /\right.$ well) with or without $10 \mathrm{ng} / \mathrm{mL}$ of IL-1 $\beta$ were added to 16 -HBE cultures. When 16 -HBE cells grew to $90 \%$ confluence, a straight wound line was made across the cell monolayer using a sterile $10 \mu$ pipette tip. Wells were washed with PBS and serum-free IMDM was applied to the cells. Images were captured at 0 and 48 hours after wound creation. The area between the wound edges was measured at each time point using Image $\mathrm{J}$ software. The remaining wound areas were expressed as a percentage of area at time 0 and calculated by the formula: $\%$ of wound closure $=($ measurement at $48 \mathrm{~h} /$ measurement at time $0 \mathrm{~h}) * 100$.

\section{Data analysis}

Each result is expressed as the mean \pm SEM for $\mathrm{n}$ independent experiments. Statistical analysis was performed using one-way analysis of variance with Bonferroni's post hoc test. GraphPad Prism 5.0 was used to analyze data and $P<0.05$ was considered significant.

\section{Results}

\section{Morphological changes in16-HBE cells}

Under phase contrast microscopy the 16-HBE cells cultured alone or the co-cultured 16-HBE cells with mast cells in the absence of IL-1 $\beta$ displayed a typical epithelial cobblestone-like shape and were attached to each other. In contrast, the $16-\mathrm{HBE}$ cells stimulated with IL-1 $\beta$ or co-cultured with mast cells and IL-1 $\beta$ were elongated and exhibited a spindle-shape or fibroblast-like morphology, and the cell-cell contacts were decreased or disappeared (Fig. 1). 


\section{E-cadherin and vimentin expressions in 16-HBE cells}

Protein and mRNA expression of E-cadherin was significantly down-regulated, but vimentin was significantly up-regulated in 16-HBE cells treated with IL-1 $\beta$ or the co-cultured 16-HBE with mast cells and IL-1 $\beta$ when compared with that in 16-HBE cells alone or the co-cultured 16-HBE cells with mast cells. The combination of mast cells and IL-1 $\beta$ also significantly enhanced the decrease of E-cadherin expression and increase of vimentin expression in 16-HBE cells induced by IL-1 $\beta$ alone (Fig. 2A, B). The changes of Ecadherin and vimentin expression in the IL-1 $\beta$-treated 16-HBE cells were completely abrogated in the presence of anti-TGF- $\beta 1 \mathrm{mAb}$. However, in the co-cultured 16-HBE cells with mast cells and IL-1 $\beta$, antiTGF- $\beta 1 \mathrm{mAb}$ did not significantly inhibit the decrease of E-cadherin expression and the increase of vimentin expression (Fig. 3A, B). There was no significant difference in the expression of E-cadherin and vimentin between 16-HBE cells alone and the co-cultured 16-HBE cells with mast cells (Fig. 2A, B). The results indicate that IL-1 $\beta$ instead of mast cells alone could down-regulate E-cadherin expression while up-regulate vimentin expression in 16-HBE cells, but mast cells combined IL-1 $\beta$ produced a synergetic effect on E-cadherin or vimentin expression in 16-HBEcells.

\section{Production and mRNA expression of TGF- $\beta 1$}

As shown in Fig. 4A, a low concentration of TGF- $\beta 1$ could be detected in the culture supernatant of 16HBE cells or mast cells. By comparison, the level of TGF- $\beta 1$ was significantly increased in the supernatant from the IL-1 $\beta$-stimulated 16 -HBE cells or mast cells. The TGF- $\beta 1$ production from the co-culture of 16HBE cells with mast cells and IL-1 $\beta$ was also significantly greater than that from 16-HBE cells or mast cells treated with IL-1 $\beta$. RT-PCR analysis showed that IL-1 $\beta$ significantly promoted TGF- $\beta 1$ expression in 16-HBE cells (Fig. 4B) or in mast cells (Fig. 4C). The combination of 16-HBE cells and mast cells with IL$1 \beta$ significantly enhanced TGF- $\beta 1$ expression either in 16-HBE cells (Fig. 4B) or in mast cells (Fig. 4C). The production and mRNA expression of TGF- $\beta 1$ in the co-cultured 16-HBE cells (Fig. 4A, B) or in mast cells ((Fig. 4A, C) had no significantly differences in contrast with 16-HBE cells or mast cells alone.

\section{6-HBE cell migration}

The wound area in the scratch wound healing assay indirectly reflected the migratory ability of 16-HBE cells. The smaller area means the cultured 16-HBE cells have more powerful mobility. As illustrated in Fig. 5, compared to the 16-HBE cells alone, the IL-1 $\beta$-treated 16-HBE cells, not the co-cultured 16-HBE cells with mast cells, exhibited significantly stronger migration capacity at $48 \mathrm{~h}$ of culture. When compared with the IL-1 $\beta$-treated $16-\mathrm{HBE}$ cells, a significant increase in the migration ability could be observed in the 16-HBE cells co-cultured with mast cells in the presence of IL-1 $\beta$. These results indicate that the migration of HBE cells can be induced by IL-1 $\beta$, and mast cells in combination with IL-1 $\beta$ might produce a significant additive effect on the migratory activity of 16-HBE cells.

\section{Discussion}


E-cadherin is a marker protein of epithelium and is indispensable for the maintenance of the epithelial phenotype $[24,25]$. Suppression of E-cadherin expression leads to the disassembly of cell-cell adhesion and subsequent loss of epithelial polarity, and initiates the differentiation of epithelial cells into fibroblasttype mesenchymal cells [25-27]. Vimentin is a protein expressed in mesenchymal cells, but it can also be expressed in epithelial cells where EMT occurs. Epithelial cells undergoing EMT are also characteristic of irregularly spindle-shaped appearance and powerful migration capacity [28]. In the present study, we found that mast cells alone did not affect significantly E-cadherin and vimentin expression in the cocultured 16-HBE cells, nor did affect the epithelial morphology and migration ability, suggesting that mast cells alone have not the potential to induce EMT in 16- HBE cells. Unlike mast cells, IL-1 $\beta$ significantly down-regulated E-cadherin expression while significantly upregulated vimentin expression in 16-HBE cells. Moreover, the IL-1 $\beta$-treated 16-HBE cells exhibited the morphological features of mesenchymal cells and an increasing mobility. The results indicate that IL-1 $\beta$ is able to induce $16-\mathrm{HBE}$ cells to undergo EMT.

TGF- $\beta 1$ is the most potent and most well described inducer of EMT identified so far [28]. In the normal airways, a low of level of TGF- $\beta 1$ can be secreted by airway epithelial cells and other structural cells, and is an essential growth factor for the maintaining of epithelial integrity [10]. However, repeated aggression of inflammation or exogenous irritants (allergens, infections and cigarette smoke) leads to the release of large amounts of TGF- $\beta 1$ from the damaged epithelial cells in asthmatic airways [10, 29]. Increased levels of TGF- $\beta 1$ have been reported in bronchoalveolar lavage fluid and bronchial biopsies of asthmatic patients [30,31]. A lot of studies have shown that TGF- $\beta 1$ could directly induce EMT in human bronchial epithelial cells [11-14]. Yasukawa et al. reported that eosinophils induce EMT in airway epithelial cells via increasing TGF- $\beta 1$ production [32]. In our experiment, we observed that epithelial cells cultured alone produced only a small amount of TGF- $\beta 1$, however, mRNA expression and protein production of TGF- $\beta 1$ were significantly increased in IL-1 $\beta$-treated 16-HBE cells compared with 16-HBE cells alone. In addition, in the presence of anti-TGF- $\beta 1 \mathrm{mAb}, \mathrm{IL}-1 \beta$-induced suppression of E-cadherin expression and enhancement of vimentin expression in 16-HBE cells were abrogated completely. These results indicate that the IL-1 $\beta$ could stimulate $16-\mathrm{HBE}$ cells to produce TGF- $\beta 1$ which mediated the conversion of $16-\mathrm{HBE}$ cells to mesenchymal cells.

Previous reports have demonstrated that human mast cell line LAD2 and the cultured mast cells from the progenitors in human cord blood or peripheral blood can constitutively express mRNA for TGF- $\beta 1$ and produce bioactive TGF- $\beta 1[33,34]$. In our study, the peripheral blood-derived mast cells could releasea small amount of TGF- $\beta 1$, but IL-1 $\beta$ stimulation significantly enhanced expression of both TGF- $\beta 1$ mRNA and protein in the cultured mast cells. The results provide further evidence that mast cells are also a potential source of TGF- $\beta 1$ and inflammatory stimulation is able to activate mast cells to release more TGF- $\beta 1$. It is likely that the amount of TGF- $\beta 1$ produced by $16-\mathrm{HBE}$ cells and/or mast cells in a quiescent state is too small to activate TGF- $\beta$ signaling pathway to affect the expression of E-cadherin and vimentin in 16-HBE cells, therefore, mast cells failed to induce EMT in the co-cultured 16-HBE cells.

Our study found that mast cells and 16-HBE cells in the co-culture were incapable of interacting with each other in the expression of TGF- $\beta 1$, however, when IL-1 $\beta$ was added to the co-culture, TGF- $\beta 1$ expression 
was significantly higher in the co-cultured mast cells than in IL-1 $\beta$-stimulated mast cells, and higher in the co-cultured 16-HBE cells than in IL-1 $\beta$-stimulated $16-\mathrm{HBE}$ cells. The result shows that addition of IL-1 $\beta$ could significantly enhance mRNA expression and protein production of TGF- $\beta 1$ in both 16-HBE cells and mast cells. Since activated epithelial cells or mast cells also have potential to produce a variety of biologically active mediators such as IL-4, TNF- $\alpha$ and IL- $1 \beta$, which in turn further promote TGF- $\beta 1$ expression in mast cells and epithelial cells $[10,16,35]$, therefore, the enhancing TGF- $\beta 1$ expression in the co-cultured cells with IL-1 $\beta$ may result from the stimulation of active mediators other than TGF- $\beta 1$ secreted by 16-HBE cells and/or mast cells in an autocrine/paracrine fashion.

In our experiment, mast cells alone had no effect on E-cadherin or vimentin expression in the co-cultured 16-HBE cells, however, when IL-1 $\beta$ was added to the co-cultures, E-cadherin expression was significantly decreased while vimentin expression was significantly increased in 16-HBE cells. The result indicates that EMT could be induced in the 16-HBE cells co-cultured with mast cells and IL-1 $1 \beta$. When compared with IL$1 \beta$-induced EMT of 16 -HBE cells, EMT in co-cultured 16 -HBE cells with mast cells was significantly enhanced by the addition of IL-1 $\beta$, and could not be abrogated significantly by TGF- $\beta 1$ neutralizing antibody, suggesting that the EMT was independent on TGF- $\beta 1$. Given that IL-1 $\beta$ itself induced EMT of $16-H B E$ through a TGF- $\beta 1$-dependent mechanism, mast cells may play a vital role in promoting the transformation of $16-\mathrm{HBE}$ cells to mesenchymal cells in the present of IL-1 $\beta$. As mentioned above, in addition to TGF- $\beta 1$, activated mast cells can also release multiple other profibrotic factors such as epidermal growth factor, connective tissue growth factor, fibroblast growth factor-2, IL-6, IL-1 $\beta$ and TNF-a, which have been reported to participate in epithelial $\operatorname{EMT}[7,13,14,16,29]$. Thus, it is likely that mast cells induced the TGF- $\beta 1$-independent EMT in the co-cultured 16-HBE cells by releasing some unknown EMT inducers in the presence of IL-1 $\beta$.

In conclusion, we for the first time demonstrated that IL-1 $\beta$ alone induced a TGF- $\beta 1$-dependent EMT in 16HBE cells, but human peripheral blood-derived mast cells alone failed to induce EMT of 16-HBE cells. Mast cells combined with IL-1 $\beta$ induced EMT in 16-HBE cells through a TGF- $\beta 1$-independent mechanism. Our results suggest the possibility that mast cells contribute to EMT in human bronchial epithelial cells in the inflammatory airway tissues of asthmatics.

\section{Abbreviation}

EMT, epithelial to mesenchymal transition

HBE, human bronchial epithelial

IL-1 $\beta$, interleukin-1 $\beta$

TGF- $\beta 1$, transforming growth factor- $\beta 1$

\section{Declarations}




\section{Ethics approval and consent to participate}

This study was approved by the Ethics Committee of Tongji Medical College of Huazhong University of Science and Technology,Wuhan, China. Written informed consent was obtained from all healthy volunteers beforeblood sampling.

\section{Consent for publication}

Not applicable.

\section{Availability of data and materials}

The datasets generated and analysed during the current study are available from the corresponding author on reasonable request.

\section{Competing interests}

The authors declare no conflict of interest.

\section{Authors' contributions}

XS Wang designed the research project, performed the experiments, analyzed the data, drafted the manuscript and provided research support. L Xie performed the experiments, analyzed the data and interpreted the data. KY Zheng performed parts of the experiments. Authors have read and approved the final manuscript.

\section{Acknowledgements}

This work was supported by the National Natural Science Foundation of China ( 81270062).

\section{Author details}

${ }^{1}$ Department of Pathology, Basic Medical College, Tongji Medical College, Huazhong University of Science and Technology, Wuhan, China.

${ }^{2}$ Department of Otolaryngology-Head and Neck Surgery, Tongji Hospital, Tongji Medical College, Huazhong University of Science and Technology, Wuhan, China.

\section{References}

1. Lange P, Parner J, Vestbo J, Schnohr P, Jensen G. A 15-year follow-up study of ventilatory function in adults with asthma. N Engl J Med. 1998;339: 1194-200.

2. Saglani S, Lloyd CM. Novel concepts in airway inflammation and remodeling in asthma. Eur Respir.2015;46:1796-804. 
3. Thiery JP. Epithelial-mesenchymal transitions in development and pathologies. Curr Opin. Cell Biol. 2003;15: 740-6.

4. Johnson JR, Roos A, Berg T, Nord M, Fuxe J. Chronic respiratory aeroallergen exposure in mice induces epithelial-mesenchymal transition in the large airways. PLoS One. 2011; 6: e16175.

5. Wilson J, Holgate ST, Roche WR. Myofibroblasts and subepithelial fibrosis in bronchial asthma. Am J Respir Cell Mol Biol. 1990;3: 507-11.

6. Miller M, Cho JY, McElwain K, McElwain S, Shim JY, Manni M, Baek JS, Broide DH. Corticosteroids prevent myofibroblast accumulation and airway remodeling in mice. Am J Physiol Lung Cell Mol Physiol. 2006;290: L162-9.

7. Lee $\mathrm{K}$, Nelson CM. New insights into the regulation of epithelial- mesenchymal transition and tissue fibrosis. Int Rev Cell Mol Biol. 2012;294: 171-221.

8. Borthwick LA, Wynn TA, Fisher AJ. Cytokine mediated tissue fibrosis. Biochim Biophys Acta. 2013;1832: 1049-60.

9. Ichinose M. Differences of inflammatory mechanisms in asthma and COPD. Allergol Int. 2009;58: 307-13.

10. Knight DA, Holgate ST. The airway epithelium: structural and functional properties in health and disease. Respirology.2003;8: 432-46.

11. Hackett TL, Warner SM, Stefanowicz D, Shaheen F, Pechkovsky DV, Murray LA, Argentieri R, Kicic A, Stick SM, Bai TR, Knight Induction of epithelial-mesenchymal transition in primary airway epithelial cells from patients with asthma by transforming growth factor- $\beta 1$. Am J Respir Crit Care Med. 2009;180: 122-33.

12. Fischer KD, Agrawal DK. Vitamin D regulating TGF- $\beta$ induced epithelial mesenchymal transition. Respir Res. 2014;15: 146.

13. Doerner AM, Zuraw BL. TGF- $\beta 1$ induced epithelial to mesenchymal transition (EMT) in human bronchial epithelial cells is enhanced by IL-1 $\beta$ but not abrogated by corticosteroids. Respir Res. 2009;10: 100.

14. Kamitani S, Yamauchi Y, Kawasaki S, Takami K, Takizawa H, Nagase T, Kohyama T. Simultaneous stimulation with TGF- $\beta 1$ and TNF-a induces epithelial mesenchymal transition in bronchial epithelial cells. Int Arch Allergy Immunol. 2011;155: 119-28.

15. Bradding P, Walls AF, Holgate ST. The role of the mast cell in the pathophysiology of asthma. $J$ Allergy Clin Immunol. 2006;117: 1277-84.

16. Mukai K, TsaiM, Saito H, Galli SJ. Mast cells as sources of cytokines, chemokines, and growth Immunol Rev. 2018;282: 121-50.

17. Okayama Y, Ra C, Saito H. Role of mast cells in airway remodeling. Curr Opin Immunol. 2007;19: 68793.

18. Johnson VJ, Yucesoy B, Luster MI. Prevention of IL-1 signaling attenuates airway hyperresponsiveness and inflammation in a murine model of toluene diisocyanate-induced asthma. 
J Allergy Clin Immunol. 2005;116: 851-8.

19. Dinrello CA. Immunological and inflammatory functions of the interleukin-1 family. Annu Rev Immunol. 2009;27: 519-50.

20. Maestrelli P, Di Stefano A, Occari P, Turato G, Milani G, Pivirotto F, Mapp CE, Fabbri LM, Saetta M. Cytokines in the airway mucosa of subjects with asthma induced by toluene diisocyanate. Am J Respir Crit Care Med. 1995;151: 607-12.

21. Hsieh CJ, Hall K, Ha T, Li C, Krishnaswamy G, Chi DS. Baicalein inhibits IL-1 beta- and TNF-alphainduced inflammatory cytokine production from human mast cells via regulation of the NF-kappaB pathway. Clin Mol Allergy. 2007;5: 5.

22. Chi DS, Lin TC, Hall K, Ha T, Li C, Wu ZD, Soike T, Krishnaswamy G. Enhanced effects of cigarette smoke extract on inflammatory cytokine expression in IL-1 $\beta$-activated human mast cells were inhibited by Baicalein via regulation of the NF-KB pathway. Clin Mol Allergy. 2012;10: 3.

23. Wang XS, Sam SW, Yip KH, Lau HY. Functional characterization of human mast cells cultured from adult peripheral blood. Int Immunopharmacol. 2006;6: 839-47.

24. Tepass U, Truong K, Godt D, Ikura M, Peifer M. Cadherins in embryonicand neural morphogenesis. Nat Rev Mol Cell Biol.2000;1: 91-100.

25. Arias AM. Epithelial mesenchymal interactions in cancer and development. Cell. 2001;105: 425-31.

26. Vleminckx K, Kemler R. Cadherins and tissue formation: integrating adhesion and signaling. 1999;21: 211-20.

27. Nightingale J, Patel S, Suzuki N, Buxton R, Takagi Ken-Ichro, Suzuki J, Sumi Y, Imaizumi A, Mason RM, Zhang Z. Oncostatin M, a cytokine released by activated mononuclear cells, induces epithelial cell-myofibroblast transdifferentiation via Jak/Stat pathway activation. J Am Soc Nephrol. 2004;15: 21-32.

28. Zavadil J, Böttinger EP. TGF-beta and epithelial-to-mesenchymal transitions. Oncogene. 2005;24: 5764-74.

29. Crosby LM, Waters CM. Epithelial repair mechanisms in the lung. Am J Physiol Lung Cell Mol Physiol. 2010;298: L715-L31.

30. Redington AE, Madden J, Frew AJ, Djukanovic R, Roche WR, Holgate ST, Howarth PH. Transforming growth factor- $\beta 1$ in asthma. Measurement in bronchoalveolar lavage fluid. Am J Respir Crit Care Med.1997;156: 642-7.

31. Chakir J, Shannon J, Molet S, Fukakusa M, Elias J, Laviolette M, Boulet Louis-Philippe, Hamid Q. Airway remodeling-associated mediators in moderate to severe asthma: effect of steroids on TGF- $\beta$, IL-11, IL-17, and type I and type III collagen expression. J Allergy Clin Immunol.2003;111: 1293-98.

32. Yasukawa A, Hosoki K, Toda M, Miyake Y, Matsushima Y, Matsumoto T, Boveda-Ruiz D, Gil-Bernabe P, Nagao M, Sugimoto M, Hiraguchi Y, Tokuda R, Naito M, Takagi T, D’Alessandro-Gabazza CN, Suga S, Kobayashi T, Fujisawa T, Taguchi O, Gabazza EC. Eosinophils promote epithelial to mesenchymal transition of bronchial epithelial cells. PLoS One. 2013; 8: e64281. 
33. Kanbe N, Kurosawa M, Nagata H, Saitoh H, Miyachi Y. Cord blood-derived human cultured mast cells produce transforming growth factor beta1. Clin Exp Allergy. 1999;29: 105-13.

34. Cho SH, Lee SH, Kato A, Takabayashi T, Kulka M, Shin SC, Schleimer RP. Cross-talk between human mast cells and bronchial epithelial cells in plasminogen activator inhibitor-1 production via transforming growth factor- $\beta 1$. Am J Respir Cell Mol Biol.2015;52: 88-95.

35. Holgate ST, Lackie PM, Davies DE, Roche WR, Walls AF. The bronchial epithelium as a key regulator of airway inflammation and remodeling in asthma. Clin Exp Allergy. 1999;29(Suppl.2): 90-5.

\section{Figures}

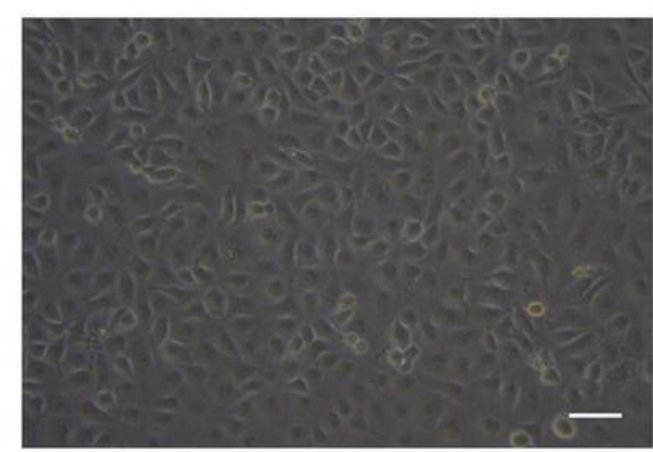

Control

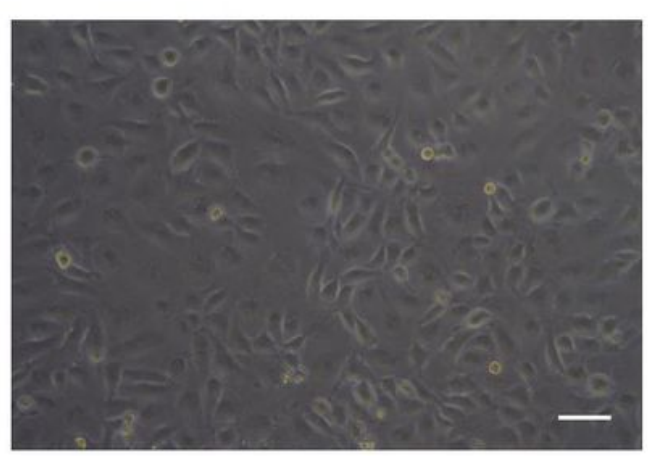

$+\mathrm{IL}-\mathbf{1 \beta}$

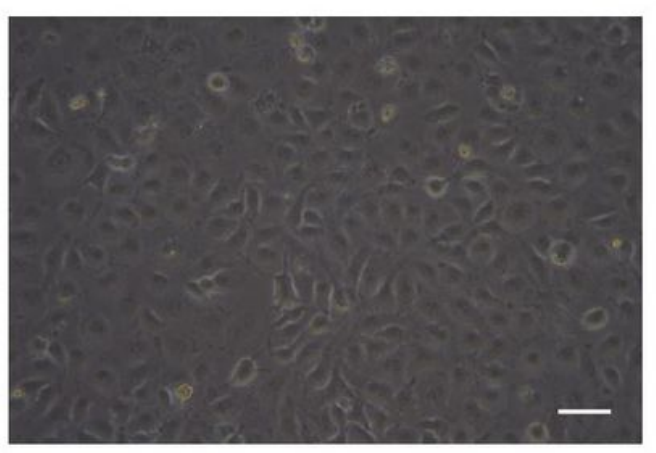

$+\mathrm{MC}$

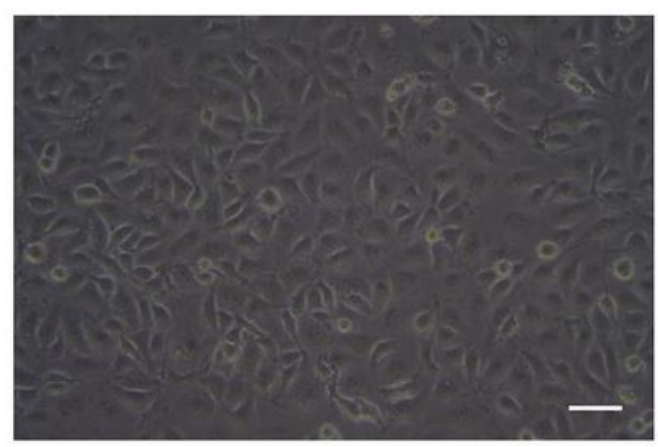

$+\mathrm{MC}+\mathrm{IL}-1 \beta$

\section{Figure 1}

Morphological changes in 16-HBE cells cultured under different conditions. HBE, 16-HBE cells; MC, mast cell; IL-1 $\beta$, interleukin-1 $\beta$. Scale bar $40 \mu \mathrm{m}$. 
A
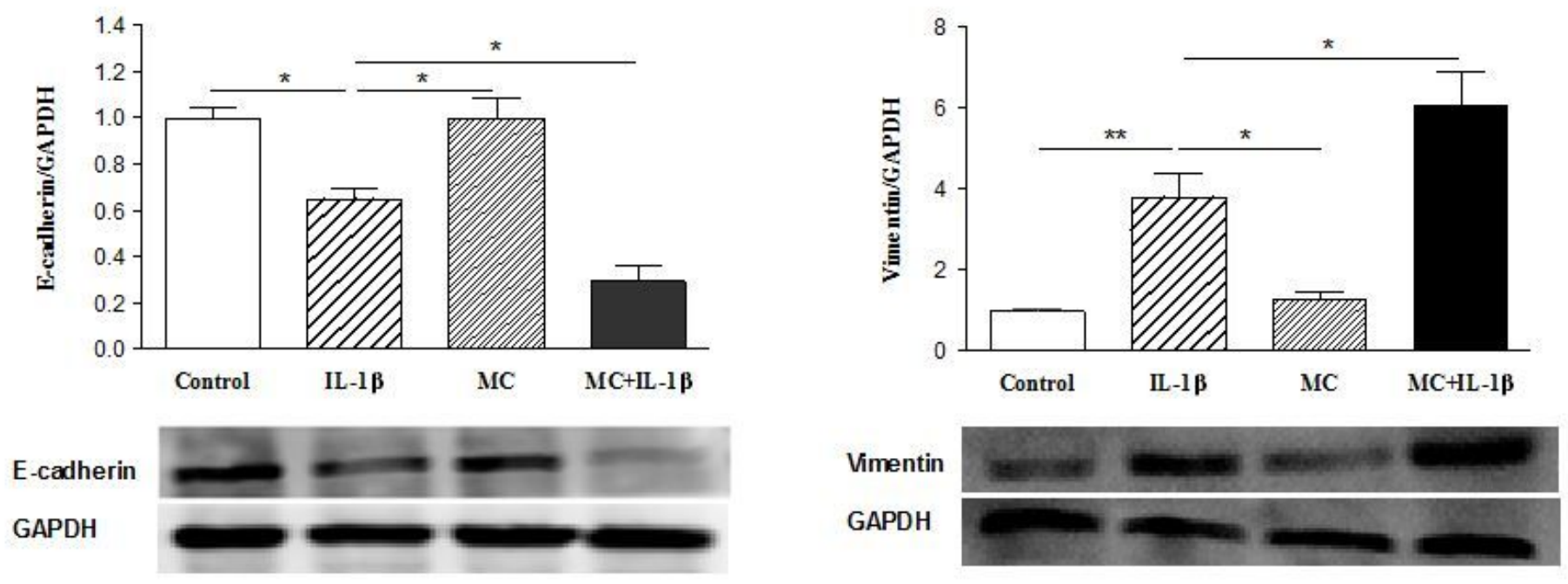

B
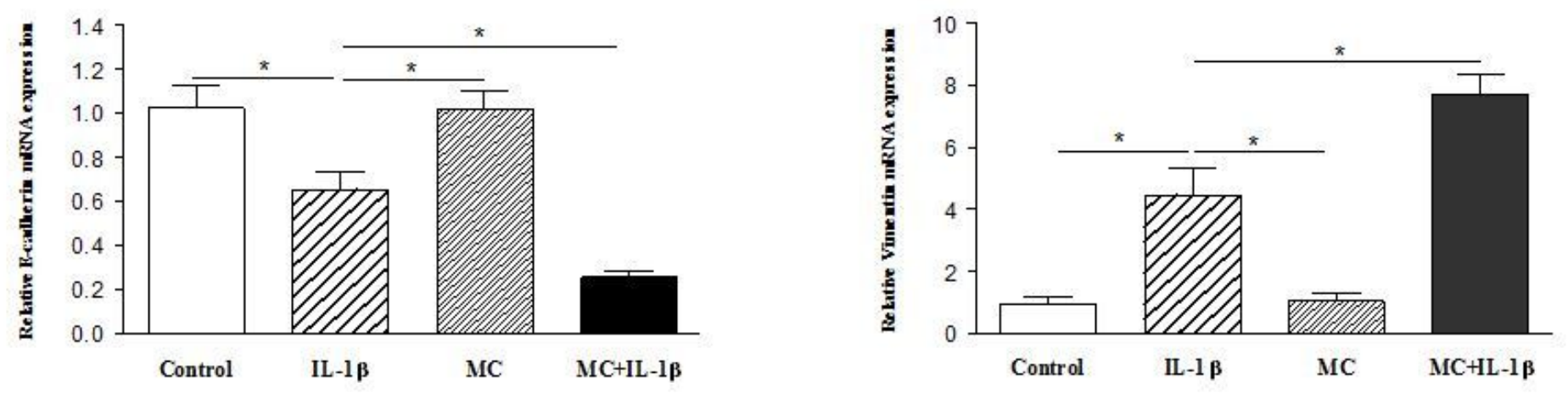

Figure 2

Expression of E-cadherin and vimentin in 16-HBE cells cultured under different conditions. (A) Protein expression of E-cadherin and vimentin in 16-HBE cells. (B) mRNA expression of E-cadherin and vimentin in $16-\mathrm{HBE}$ cells. Data are expressed as mean \pm SEM for $3 \llbracket 5$ experiments. ${ }^{*} \mathrm{p} \otimes 0.05,{ }^{\star}{ }^{*} \mathrm{P}<0.01$. HBE, $16-\mathrm{HBE}$ cells; MC, mast cell; IL-1 $\beta$, interleukin-1 $\beta$. 

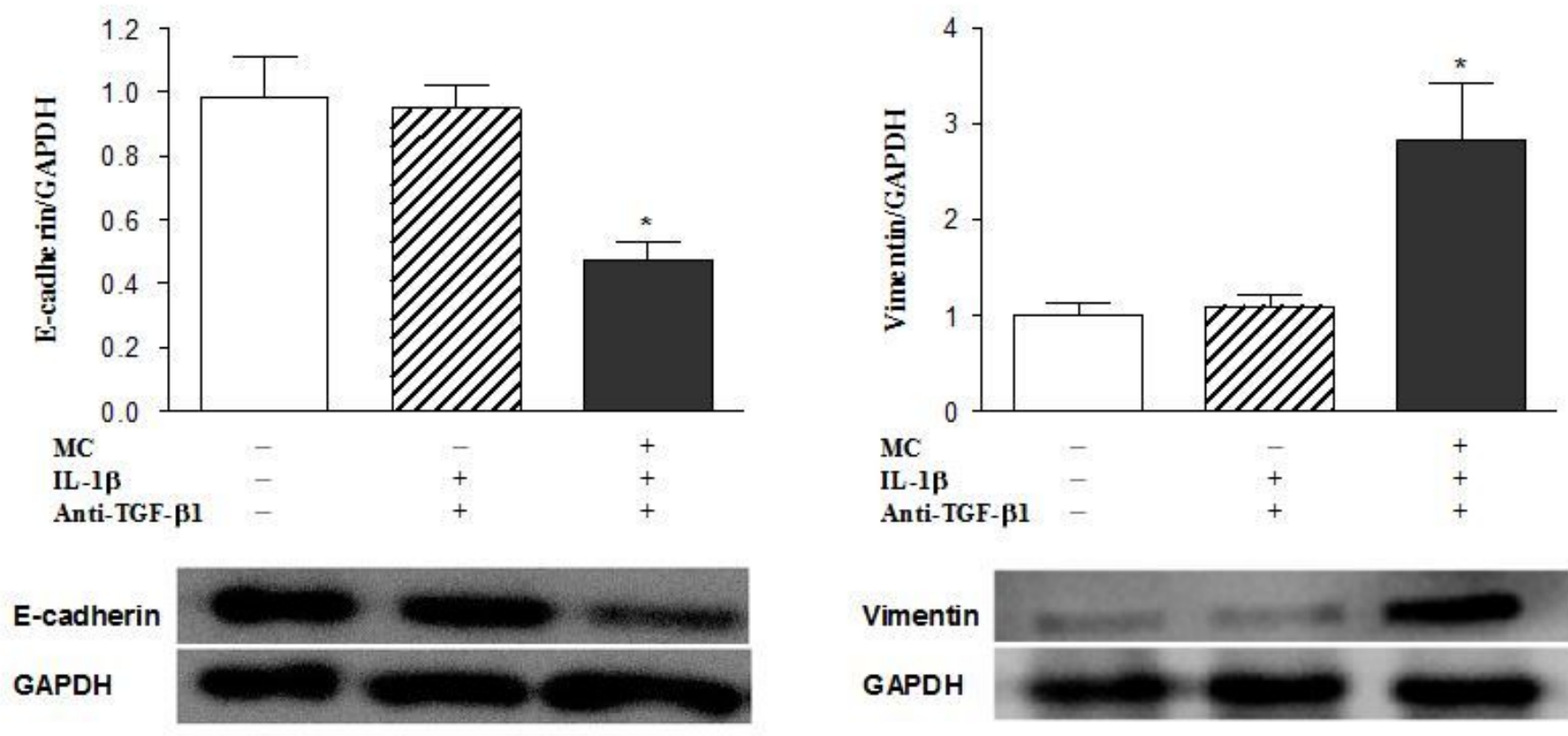

Vimentin

GAPDH

B
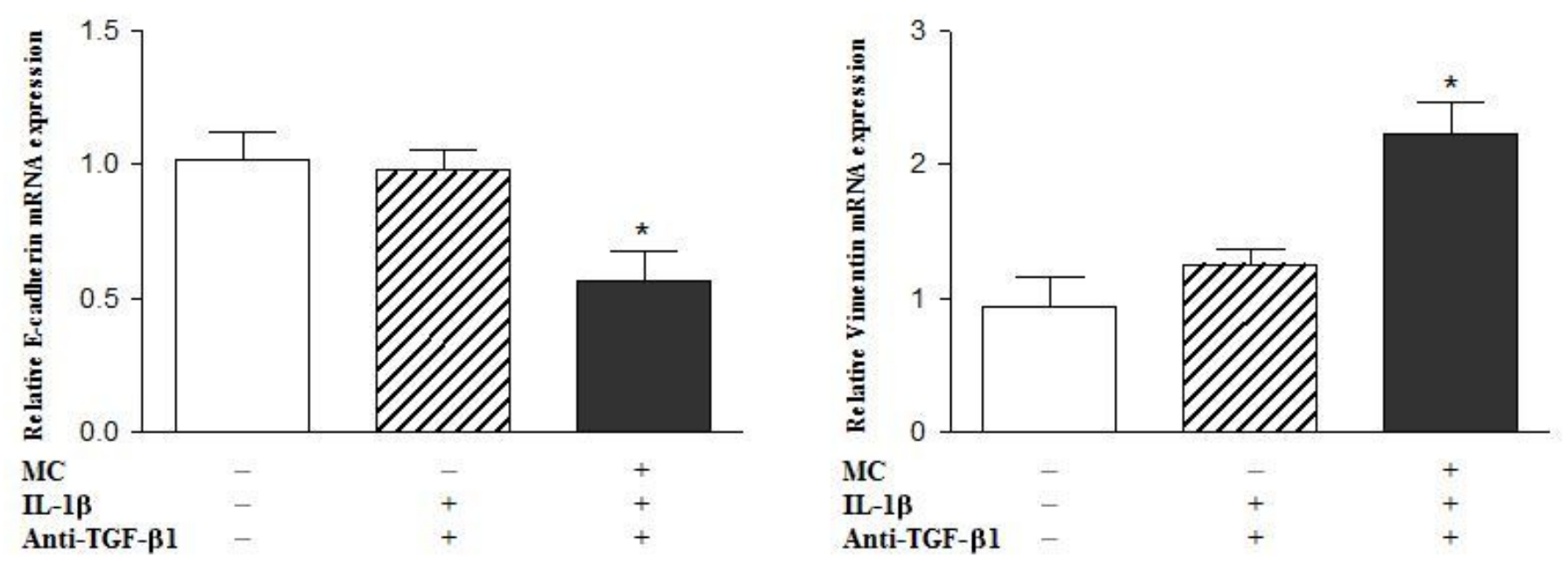

\section{Figure 3}

Expression of E-cadherin and vimentin in 16-HBE cells cultured under different conditions. (A) Protein expression of E-cadherin and vimentin in 16-HBE cells in the absence and presence of anti-TGF- $\beta 1 \mathrm{mAb}$. (B) mRNA expression of E-cadherin and vimentin in 16-HBE cells in the absence and presence of antiTGF- $\beta 1 \mathrm{mAb}$. Data are expressed as mean \pm SEM for $3 \llbracket 5$ experiments. * $\mathrm{p} \otimes 0.05$ vs HBE or HBE $+\mathrm{IL}-1 \beta+$ anti-TGF- $\beta 1$ mAb. HBE, 16-HBE cells; MC, mast cell; IL-1 $\beta$, interleukin-1 $\beta$. 

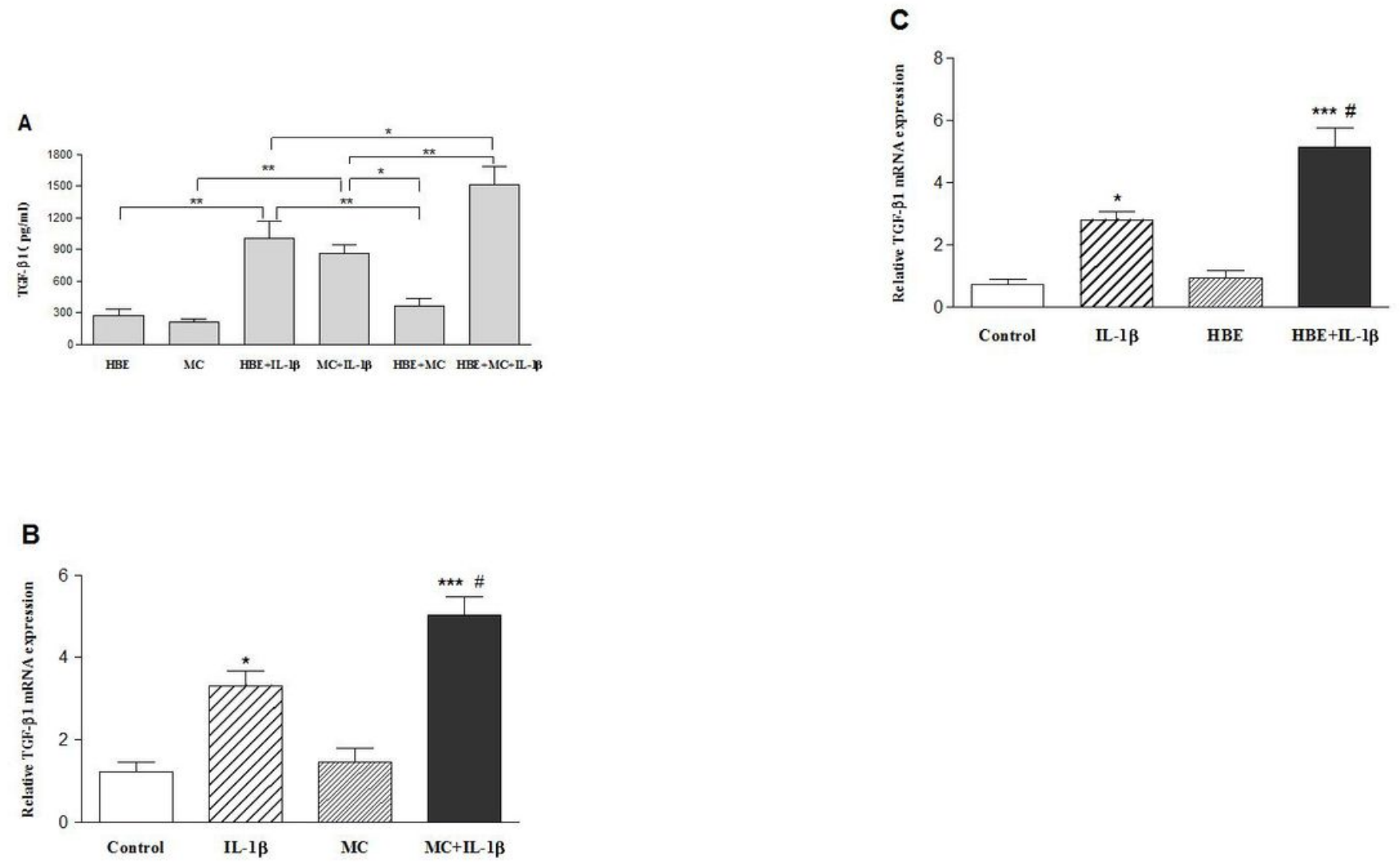

Figure 4

Production and mRNA expression of TGF- $\beta 1$ in $16-\mathrm{HBE}$ cells and mast cells. (A) Concentration of TGF- $\beta 1$ in the supernatants of cultured cells under different conditions. ${ }^{*}<<0.05,{ }^{*} \mathrm{P}<0.01$ by Tukey's post-hoc analysis after one-way ANOVA. (B) TGF- $\beta 1$ mRNA expression in cultured 16-HBE cells under different conditions. ${ }^{*} \mathrm{p} \otimes 0.05,{ }^{* \star *} \mathrm{P}<0.001$ vs. HBE (control) or HBC+MC. $\# \mathrm{p} \otimes 0.05$ vs HBE+IL-1 $\beta$. (C) TGF- $\beta 1 \mathrm{mRNA}$ expression in cultured mast cells under different condition. ${ }^{*} \mathrm{p} \otimes 0.05, * \star * \mathrm{P}<0.001$ vs. $\mathrm{MC}$ (control) or $\mathrm{MC}+\mathrm{HBE}$. \#p $₫ 0.05$ vs MC+IL-1 $\beta$. All data are expressed as mean \pm SEM for $3 \llbracket 4$ independent experiments.

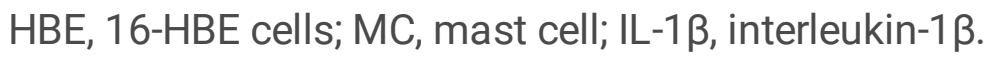



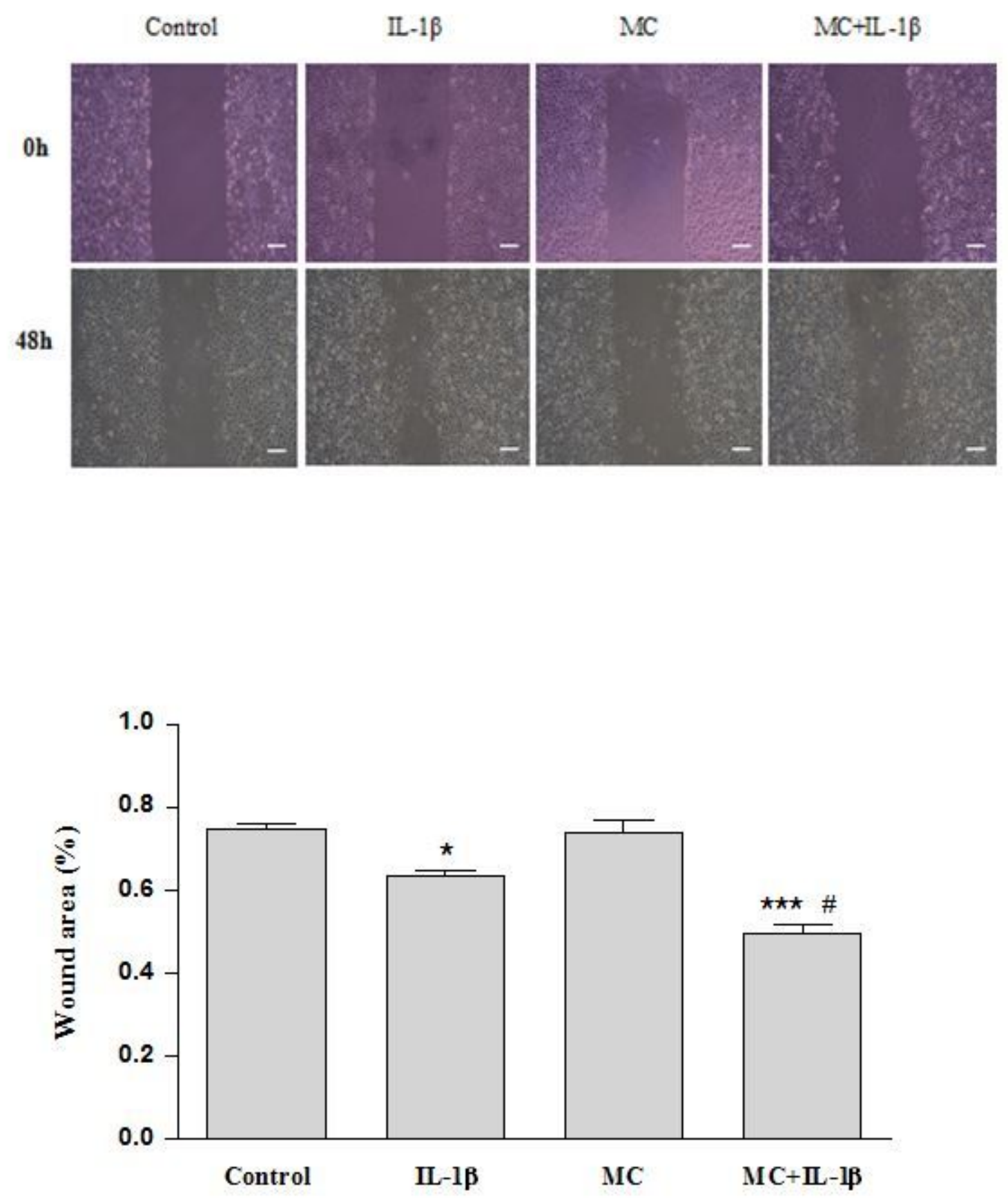

Figure 5

Effect of mast cells with or without IL-1 $\beta$ on the migration of the 16-HBE cells. The wound area values (\%) are mean $\pm \mathrm{SEM}$ for 3 experiments. ${ }^{*} \mathrm{P}<0.05$, ${ }^{\star \star *} \mathrm{P}<0.001 \mathrm{vs}$. HBE (control) or HBE+MC. \#pख0.01vs HBE+IL-

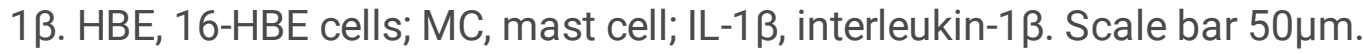

